\title{
MODEL KONSEPTUAL ADAPTASI RUANG KAMPUNG KOTA SEBAGAI AKIBAT KEBERADAAN SEKTOR PERDAGANGAN FORMAL (KAMPUNG SEKAYU KOTA SEMARANG)
}

\author{
Conceptual Model of Urban Kampong Cities as a Adaptation Result \\ of The Formal Sector Trade (Kampong Sekayu Semarang)
}

\section{Wulan Dwi Purnamasari ${ }^{1}$}

\author{
Diterima: 20 Februari 2013 Disetujui: 29 April 2013
}

\begin{abstract}
Abstrak: Menjamurnya sektor informal secara perlahan mempengaruhi penggunaan ruang dan berpengaruh pada bentuk morfologi Kampung Sekayu dilihat dari perubahan arah sirkulasi maupun pergerakan dan perubahan ruang untuk interaksi. Model perubahan/ penyesuaian Kampung Sekayu ditampilkan dalam bentuk matriks, diagram, dan mapping dengan menggunakan simbol yang diadaptasi dari teori Zahnd (2008) dimana sebelumnya dilakukan analisis kuantitatif untuk mengetahui kategori perubahan yang terjadi. Dengan bertitik tolak pada teori Lazarus (1984) mengenai penyesuaian, maka dari hasil penelitian ini terlihat bahwa aktivitas warga di Kampung Sekayu merupakan bentuk adaptasi karena warga berusaha menjadi bagian dari berkembangnya sektor perdagangan formal yang cukup pesat. Setiap aktivitas membutuhkan ruang sebagai wadah. Dalam hal ini, perubahan ruang yang terjadi di Kampung Sekayu merupakan bentuk adjustment karena beberapa ruang yang tersedia (seperti ruang publik) difungsikan untuk mendukung usaha yang dilakukan dalam hal ini usaha oleh PKL dan tukang parkir.
\end{abstract}

\section{Keywords : Penyesuaian Diri, Sektor Perdagangan Formal, Adaptasi dan Adjustment}

\begin{abstract}
The Growing up of Informal Sector is slowly affected space use and the morphological forms Kampung Sekayu, views of the circulation or movement changes and changes in space for. The model changes of Kampung Sekayu shown in matrix form, diagrams, and mapping by using symbols was adapted from Zahnd theory (2008) which were previously done uantitative analysis to know the category changes.Based on the theory of Lazarus (1984) about the adjustment, the results of this study shows that the activities of people in Kampung Sekayu is an adaptation because people trying to be part of the formal trade sector that grows rapidly. Each activity requires space as a container. In this case, the changes is happening in Kampung Sekayu is a form of adjustment due to some space available (such as public space) is intended to support the work done by street vendors and parking attendants.
\end{abstract}

Keywords: Adjustment, Formal Trade Sector, Adaptation and Adjustment

\footnotetext{
1 Jurusan Perencanaan Wilayah dan Kota, Universitas Brawijaya J1 MT Haryono No. 167 Kota Malang - 65145
} 


\section{Pendahuluan}

Perkembangan sektor perdagangan formal menjadi indikator modernitas yang sedang terjadi di kota besar. Umumnya sektor ini berada di koridor jalan utama yang terletak di depan blok-blok permukiman dan umumnya berupa sebuah kampung kota.

Kampung saat ini yang dikelilingi oleh bangunan sektor perdagangan formal secara langsung maupun tidak langsung akan terpengaruh. Sektor perdagangan formal sebagai bangunan baru didalam lingkungan kampung tidak hanya berpengaruh secara visual, namun pola-pola kegiatan atau aktivitas disekeliling bangunan itu pun juga akan ikut berubah (Broadbent (1980) dalam Susanto (1987)). Besar kecilnya perubahan tergantung pilihan warganya untuk menyesuaikan diri (beradaptasi) atau tetap memilih bertahan tanpa terpengaruh dengan keberadaan sektor perdagangan formal yang tumbuh didepannya.

Bagi kampung yang mampu beradaptasi, tidak banyak masalah yang ditimbulkan karena keberadaan sektor perdagangan formal memberi keuntungan dalam hal peningkatan kualitas kehidupan warga setempat. Namun bagi kampung yang tidak mampu beradaptasi dengan keberadaan sektor tersebut, maka dikhwatirkan akan berdampak pada munculnya konflik sosial karena adanya kesenjangan tingkat perekonomian maupun gaya hidup antara warga kampung dengan sektor perdagangan formal yang identik dengan modernitas. Secara garis besar, masalah yang akan timbul jika sebuah kampung tidak mampu beradaptasi dengan keberadaan sektor perdagangan formal adalah :

1. Adanya kesenjangan/ gap antara kampung (masyarakat menengah namun sebagian besar menengah ke bawah) dengan sektor perdagangan formal yang terdapat di bagian depan kampung dimana mencerminkan golongan menengah hingga menengah ke atas.

2. Hal tersebut akan memicu terjadinya kecemburuan sosial warga kampung terhadap sektor tersebut.

3. Dikhawatirkan berdampak pada terjadinya konflik sosial yang tercermin pada tindakan kriminalitas yang semakin meningkat dan menganggu keamanan serta kenyamanan kedua belah pihak.

Kampung Sekayu sebagai salah satu kampung kota yang berada dibelakang gedunggedung sektor formal khususnya perdagangan formal di Jalan Pemuda dan Jalan Thamrin, Kota Semarang, tidak menunjukkan fenomena yang telah dipaparkan sebelumnya. Kampung Sekayu seperti menjadi bagian dari perkembangan sektor tersebut dengan beradaptasi. Identifikasi awal mengenai bentuk adaptasi yang dilakukan Kampung Sekayu terlihat dari adanya beberapa perubahan, yaitu :

1. Jalan kampung yang dahulu menjadi ruang publik bagi masyarakat setempat untuk berbincang-bincang, sejak berkembangnya sektor formal di Jalan Pemuda khususnya Paragon menjadikan jalan kampung hanya digunakan untuk lalu lalang kendaraan yang semakin ramai.

2. Beberapa ruang publik kampung Sekayu berubah untuk kepentingan sektor formal dalam hal ini Mall Paragon, seperti ruang parkir dan sektor informal (PKL).

3. Wilayah administrasi kampung (baik resmi maupun "sejarah") berubah karena salah satu RT telah menjadi area perluasan parkir Mall Paragon.

4. Perubahan sirkulasi dari dan menuju Kampung Sekayu dimana harus mengambil jalan memutar atau melawan jalur karena adanya beton pembatas yang dibuat oleh pihak Mall Paragon.

5. Kebutuhan akan kost-kostan yang semakin meningkat sehingga kecenderungan massa bangunan menjadi 2 lantai dan semakin tidak memperhatikan bangunan yang berada disekitarnya. 
6. Banyak pendatang yang masuk dan menjadi bagian Kampung Sekayu dengan kultur yang berbeda sehingga dibutuhkan penyesuaian.

7. Sejak ramainya sirkulasi didalam kampung (dijadikan juga sebagai jalan pintas dari jalan Thamrin menuju Jalan Pemuda) akibat tarikan sektor formal, menyebabkan masyarakat mulai meningkatkan keamanan kampung dengan membatasi rumah dengan pagar dan mendirikan tiang di tengah jalan kampung agar tidak dapat dilalui mobil.

8. Pembangunan pagar pada rumah-rumah warga menjadikan individualistik masyarakat meningkat. Terlihat dari intensitas interaksi yang semakin berkurang.

Gambaran di atas memunculkan pertanyaan mengenai bagaimana model adaptasi ruang kota di Kampung Sekayu sebagai akibat keberadaan sektor perdagangan formal?

\section{Pemahaman Adaptasi}

Adaptasi merupakan salah satu bentuk penyesuaian diri terhadap lingkungan. Lebih jelas Schneiders (1964: 51) mendefinisikan penyesuaian diri sebagai berikut:

"A process, involving both mental and behavioral responses, by which an individual strives to cope successfully with inner, needs, tensions, frustration, and conflicts, and to effect a degree of harmony between these inner demands and those imposed on him by objective world in which the lives".

Adaptasi merupakan suatu bentuk proses perubahan morfologi akibat adanya perubahan kebutuhan masyarakat.

"In small historic towns adaptations in pattern of land and building utilization to changing economic and social requirements were relatively easy until major innovations (Conzen, 2004).

Masuk kedalam spesifikasi ilmu, maka secara obyektif Gifford (2002) menambahkan bahwa adaptasi dipengaruhi oleh aktivitas penghuni dalam lingkungan hunian ditambah susunan ruang dalam lingkungan itu sendiri. Oleh karena itu, adaptasi terdiri dari 3 proses, yaitu (Soemarwoto, 1991; Environmental and Human Adaptation 2006):

1. Sikap atau tingkah laku (adaptasi kultural).

2. Fisiologi (adaptasi fungsi ruang),

3. Morfologi (adaptasi bentuk ruang),

\section{Metode Penelitian}

Dengan melihat latar belakang masalah dan tujuan, maka penelitian ini termasuk dalam exploratif research. Menurut Singarimbun dan Efendi (1989), penelitian eksploratif bersifat terbuka. Dikatakan terbuka karena masih mencari-cari permasalahan yang terdapat di dalam penelitian tersebut. Penelitian ini terlihat sederhana. Sebelum terkumpul sejumlah jawaban, belum diketahui dengan pasti model adaptasi ruang yang dilakukan oleh warga Kampung Sekayu. Dalam memenuhi kebutuhan dan penelitian ini dilakukan pengumpulan data terhadap objek yang akan diteliti. 


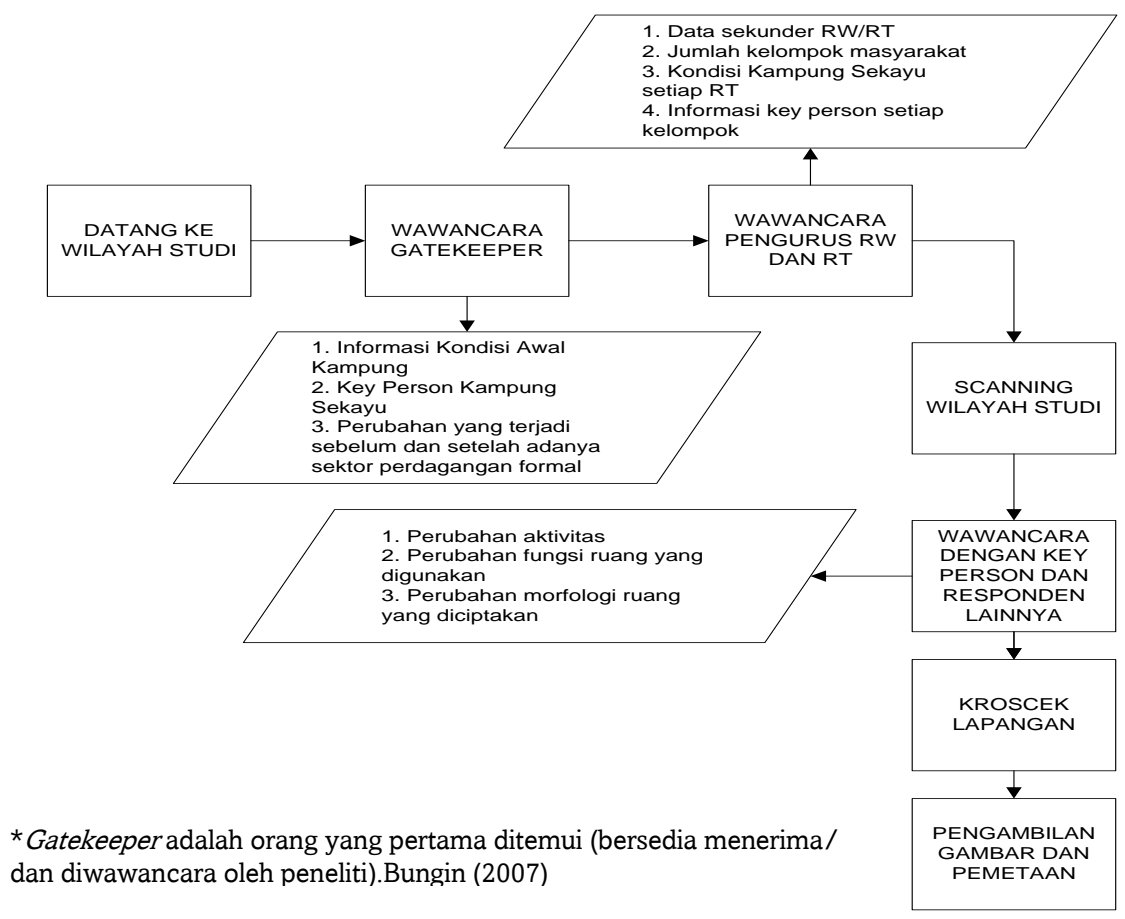

Sumber: Hasil Analisa Penyusun (2013) Menurut Bungin (2007)

\section{Gambar 1. Skema Pengambilan Data Di Kampung Sekayu}

Dalam analisis model adaptasi warga Kampung Sekayu, tahapan analisis yang akan dilakukan terdiri atas analisis kuantitatif dan kualitatif. Analisis kuantitatif digunakan pada tahap awal analisis yang bertujuan untuk mengolah data statistik yang diperoleh di Kampung Sekayu. Analisis ini menggunakan skala likert. Sedangkan analisis kualitatif didapatkan dari hasil wawancara yang bertujuan untuk memperkaya temuan hasil kuantitatif. Tahapan analisis kualitatif adalah Pembentukan Konsep Model dan Penggambaran Model Adaptasi Ruang.

\section{Pembahasan}

Secara garis besar keberadaan sektor perdagangan formal mempengaruhi aktivitas yang dilakukan oleh warga. Terlihat dari modus (dominasi) jawaban kelompok warga yang menyatakan bahwa terjadi perubahan walaupun masih dalam kategori perubahan kecil/ sedikit.

Tabel 1. Modus (Dominasi) Pilihan Kelompok Warga Kampung Sekayu Terhadap Perubahan Aktivitas Yang Berlangsung Akibat Keberadaan Sektor Perdagangan Formal

\begin{tabular}{cll}
\hline $\begin{array}{c}\text { Variabel Adaptasi } \\
\text { Aktviitas }\end{array}$ & \multicolumn{1}{c}{ Kriteria } & \multicolumn{1}{c}{ Modus Pilihan Kelompok Warga } \\
\hline Fokus Aktivitas & Jenis Pengguna & Perubahan kategori sedang \\
& Jenis Ruang & Perubahan kategori kecil \\
& Lokasi aktivitas & Perubahan kategori kecil \\
& Pihak yang terlibat & Perubahan kategori kecil \\
Jenis Aktivitas & Lingkaran aktivitas & Tidak terjadi perubahan \\
& Proses kemunculan aktivitas & Tidak terjadi perubahan \\
& Alasan aktivitas dilakukan & Perubahan kategori kecil \\
\hline
\end{tabular}




\begin{tabular}{cll}
\hline $\begin{array}{c}\text { Variabel Adaptasi } \\
\text { Aktviitas }\end{array}$ & \multicolumn{1}{c}{ Kriteria } & \multicolumn{1}{c}{ Modus Pilihan Kelompok Warga } \\
\hline Waktu Aktivitas & Waktu sibuk & Perubahan kategori kecil \\
& Waktu bersosialisasi & Perubahan kategori kecil \\
& Lama waktu bergaul/ bersosialisasi & Perubahan kategori kecil \\
& Intensitas/ Frekuensi Bergaul & Perubahan kategori kecil \\
& Jumlah warga yang ikut bersosialisasi & Perubahan kategori kecil \\
& Peranan aktivitas & Tidak terjadi perubahan \\
Keterkaitan Aktivitas & Dampak & Perubahan kategori sedang \\
& Posisi aktivitas & Perubahan kategori sedang \\
\hline
\end{tabular}

Sumber : Hasil Survey Primer Tahun 2012

\section{Model Adaptasi Perilaku Warga Kampung Sekayu Terhadap Sektor Perdagangan Formal}

Adaptasi sebagai salah satu bentuk penyesuaian diri dilakukan dengan tujuan untuk mengurangi resiko konflik sosial yang akan timbul antara sektor perdagangan formal dan perkampungan warga. Seluruh adaptasi yang terjadi dimulai dari perubahan perilaku warga setempat dalam menerima keberadaan sektor perdagangan formal yang ada dan berusaha membaur ke dalam aktivitas baru yang mereka timbulkan. Dalam paparan ini akan dibahas mengenai model adaptasi warga Kampung Sekayu yang dilihat dari perilaku dan aktivitas yang ditimbulkan sebelum dan setelah keberadaan sektor perdagangan formal di wilayah lingkungan hunian mereka.

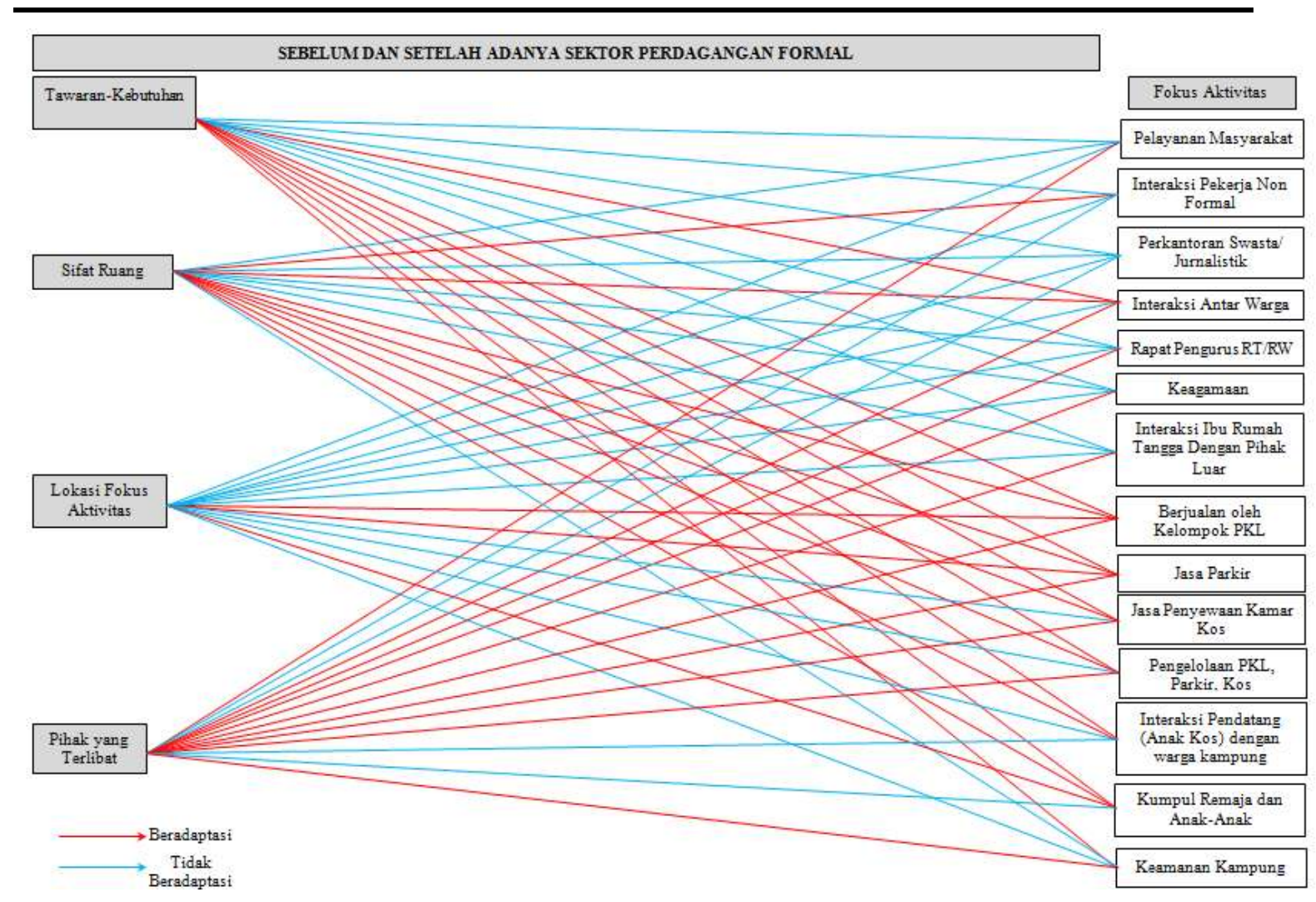

Gambar 1 Diagram Konsep Adaptasi Fokus Aktivitas Warga Kampung Sekayu 
1) Fokus Aktivitas

Aktivitas yang dilakukan membutuhkan ruang untuk pelaksanaannya. Umumnya fokus aktivitas pada kategori ini dilakukan pada ruang privat, namun ada juga yang menggunakan ruang publik di Kampung Sekayu. Ruang publik digunakan dengan alasan :

- Tidak adanya ruang privat khusus untuk pelaksanaan kegiatan.

- Setiap anggota kelompok dalam aktvitas tersebut tidak merasa membutuhkan ruang khusus.

- Frekuensi pelaksanaan kegiatan yang berkala sehingga dirasa tidak diperlukan adanya penambahan ruang khusus

Adapun adaptasi fokus aktivitas dinilai dari kelompok/ individu yang terkait dengan perkembangan Kampung Sekayu, yaitu :

- Individu/ Kelompok yang Muncul Sebelum Adanya Sektor Perdagangan Formal

- Individu/ Kelompok yang muncul sebagai respon atas keberadaan sektor perdagangan formal

- Individu/Kelompok yang sebelumnya tidak aktif namun saat ini aktif kembali sebagai respon atas keberadaan sektor perdagangan fromal

- Kelompok yang jarang/ bahkan menghilang sejak keberadaan sektor perdagangan formal

2) Jenis Aktivitas

Adaptasi jenis aktivitas di Kampung Sekayu dapat dilihat dari struktur usia pelaku, gender pelaku, alasan aktivitas dilakukan (ekonomi/ pendidikan/budaya).

\begin{tabular}{|c|c|c|c|c|c|c|c|c|}
\hline \multirow{2}{*}{$\begin{array}{c}\text { Jenis } \\
\text { Aktivitas } \\
\text { Bertemu/ }\end{array}$} & \multirow{2}{*}{$\begin{array}{c}\text { Ketegori } \\
\text { Perubahan }\end{array}$} & \multicolumn{2}{|c|}{ Lingkaran Aktivitas } & \multicolumn{2}{|c|}{ Proses Terbentuk } & \multicolumn{2}{|c|}{ Alasan Kegiatan Dilakukan } & \multirow{2}{*}{ Photo Mapping dan Keterangan } \\
\hline & & Sebelum & Sesudah & Sebelum & Sesudah & Sebelum & $\begin{array}{c}\text { Sesudah } \\
\end{array}$ & \\
\hline $\begin{array}{c}\text { Bertemu/ } \\
\text { bertegur sapa }\end{array}$ & & individu & individu & spontan & spontan & $\begin{array}{c}\text { Budaya yang } \\
\text { menjadikan } \\
\text { kebiasaan untuk } \\
\text { saling menyaps } \\
\text { ketika } \\
\text { berpapasan }\end{array}$ & $\begin{array}{c}\text { Budaya yang } \\
\text { menjadikan juga } \\
\text { menjadi kebiasaan } \\
\text { pendatang terhadap } \\
\text { penduduk asli ketiks } \\
\text { saling betemu di jalan }\end{array}$ & \\
\hline & & & & & & & & $\begin{array}{l}\text { Sast ini, tegur sapa masih menjadi bagian } \\
\text { yang tetap ditemukan ketiks penduduk } \\
\text { Kampung Sekayu baikpendatang maupun } \\
\text { penduduk asli saling bertemu di jalan. }\end{array}$ \\
\hline Membangun & Berubah & individu & $\begin{array}{c}\text { Kelompok } \\
\text { kecil }\end{array}$ & mandiri & mandiri & $\begin{array}{c}\text { Sebalumnya, } \\
\text { aktivitas } \\
\text { menambah } \\
\text { massa bangunan } \\
\text { tidak sebanyak } \\
\text { saat ini. Hal ini } \\
\text { disebabkan } \\
\text { karens } \\
\text { peruntukkan } \\
\text { bangunan yang } \\
\text { hanya } \\
\text { difungsikan } \\
\text { untuk hunian } \\
\text { saja }\end{array}$ & $\begin{array}{l}\text { Sast ini aktivitas } \\
\text { membangun dilahukan } \\
\text { cukup tinggi karena } \\
\text { tingginya permintasn } \\
\text { pembangunan kos } \\
\text { untuk sewa sehingga } \\
\text { ada penambahan ruang } \\
\text { pada bangunan }\end{array}$ & $\begin{array}{l}\text { Saat ini intensitas masyarakat dalam } \\
\text { membangun secaravertikal semakin besar } \\
\text { mengingat kebutuhan skan rumah/ kamar } \\
\text { sewa bagi para pekerja pegawai pusat } \\
\text { perbelanjaan yang juga semakin }\end{array}$ \\
\hline
\end{tabular}

Sumber : Hasil Analisis Tahun 2012

Gambar 2. Contoh Jenis Aktivitas Berdasarkan Struktur Usia, Dominasi Gender Pelaku, Dan Alasan Kegiatan Dilakukan Sebelum Dan Sesudah Adanya Sektor Perdagangan Formal Di Lingkungan Kampung Sekayu 


\section{3) Waktu Aktivitas}

Dari hasil survey diketahui bahwa untuk 9 pelaku yang teridentifikasi pada kawasan studi, hanya pelaku aktivitas dengan kategori Tukang Parkir, Pedagang Kaki Lima, Pedagang Rumahan, Pelajar, dan Anak Kos yang mengalami banyak perubahan khususnya sejak munculnya sektor perdagangan formal di lingkungan Kampung Sekayu. Adapun aktivitas yang mengalami perubahan lebih kepada waktu bekerja dan waktu bergaul berinteraksi dengan warga lainnya.

Sebelum adanya sektor perdagangan formal yang berkembang di lingkungan Kampung Sekayu, para pelaku aktivitas tersebut tidak atau melakukan aktivitas mereka dalam frekuensi yang rendah

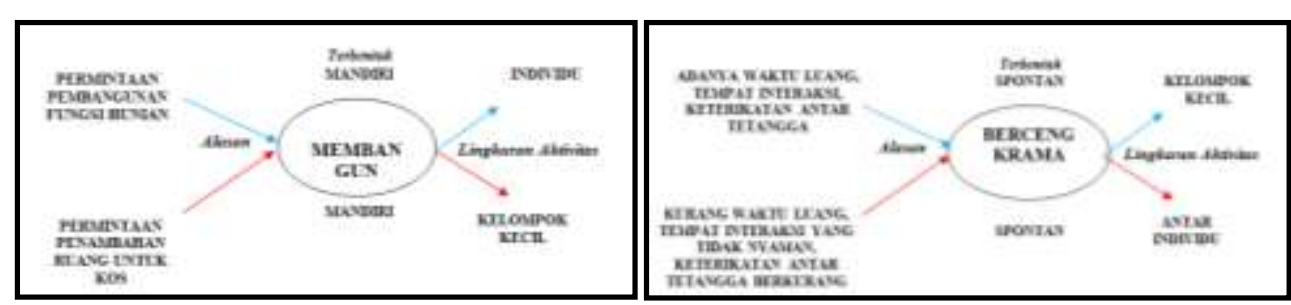

Gambar 3. Diagram Konsep Adaptasi Jenis Aktivitas Warga Kampung Sekayu
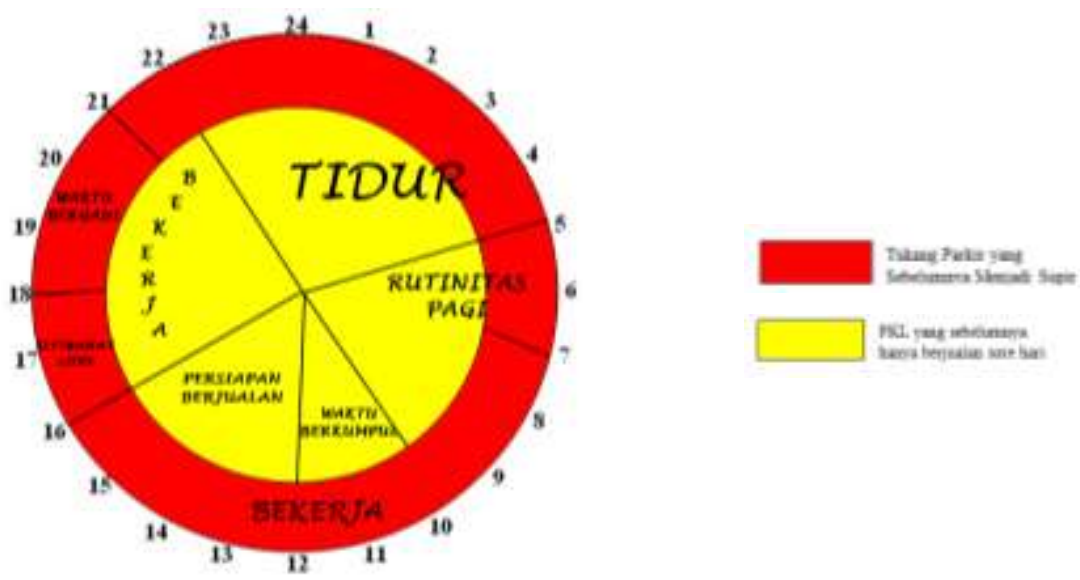

Gambar 4. Diagram Aktivitas Warga Kampung Sekayu Yang Berprofesi Sebagai Tukang Parkir Dan Pedagang Kaki Lima Sebelum Keberadaan Sektor Perdagangan Formal

4) Keterkaitan Aktivitas

Beberapa aktivitas yang teridentifikasi dilakukan oleh warga Kampung Sekayu, ternyata memiliki ketergantungan satu sama lain. Dari 14 kategori aktivitas di Kampung Sekayu, terdapat 8 jenis kategori aktivitas kelompok yang dirasa beradaptasi dengan keberadaan sektor perdagangan formal. Matrik berikut akan menguraikan bagaimana hubungan antara kedua ragam aktivitas tersebut, jenis mana yang lebih dominan, aktivitas pendukung satu dengan lainnya, dan aktivitas mana yang bersifat positif atau negatif bagi perkebangan Kampung Sekayu. 

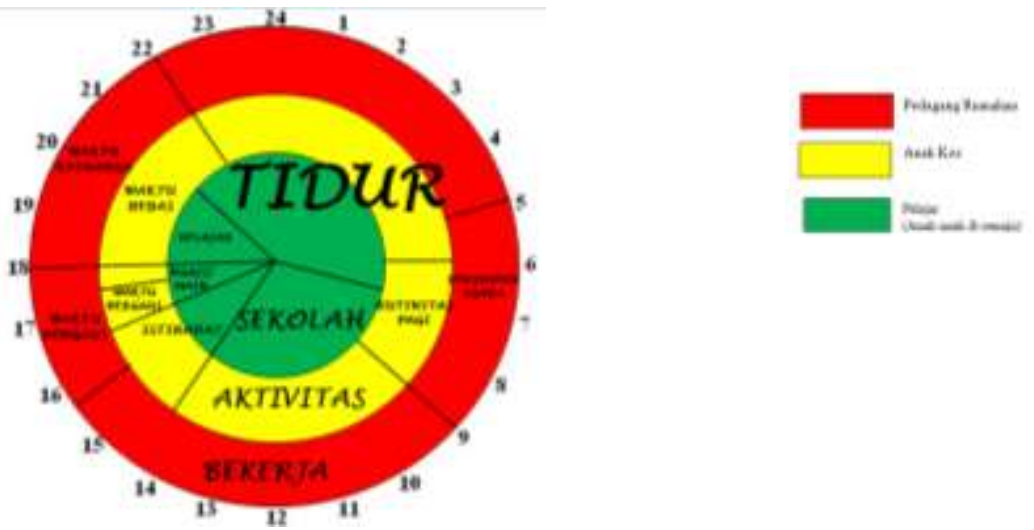

Gambar 5. Diagram Aktivitas Warga Kampung Sekayu Yang Berprofesi Sebagai Pegadang Rumahan, Anak Kos, Dan Pelajar Sebelum Keberadaan Sektor Perdagangan Formal

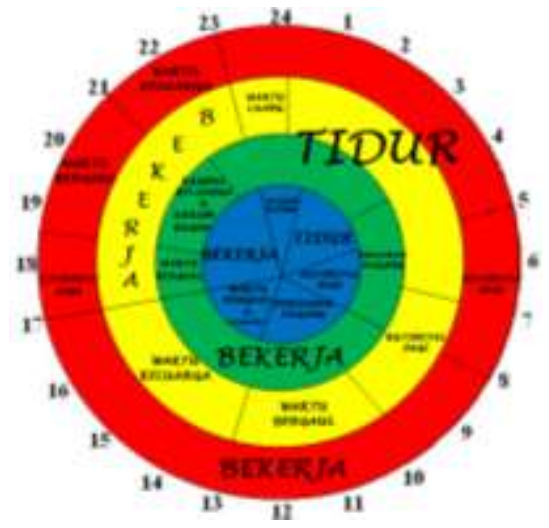

latenfortin whe ho

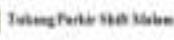

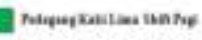

Megengkatian stansum

Gambar 6. Diagram Aktivitas Warga Kampung Sekayu Yang Berprofesi Sebagai Tukang Parkir Dan Pedagang Kaki Lima Setelah Keberadaan Sektor Perdagangan Formal

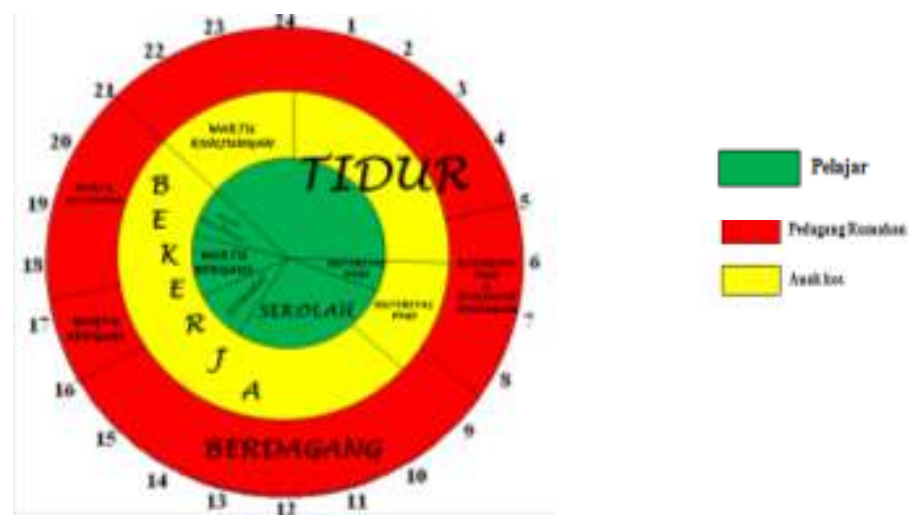

Gambar 7 . Diagram Aktivitas Warga Kampung Sekayu Yang Berprofesi Sebagai Pegadang Rumahan, Anak Kos, Dan Pelajar Setelah Keberadaan Sektor Perdagangan Formal 


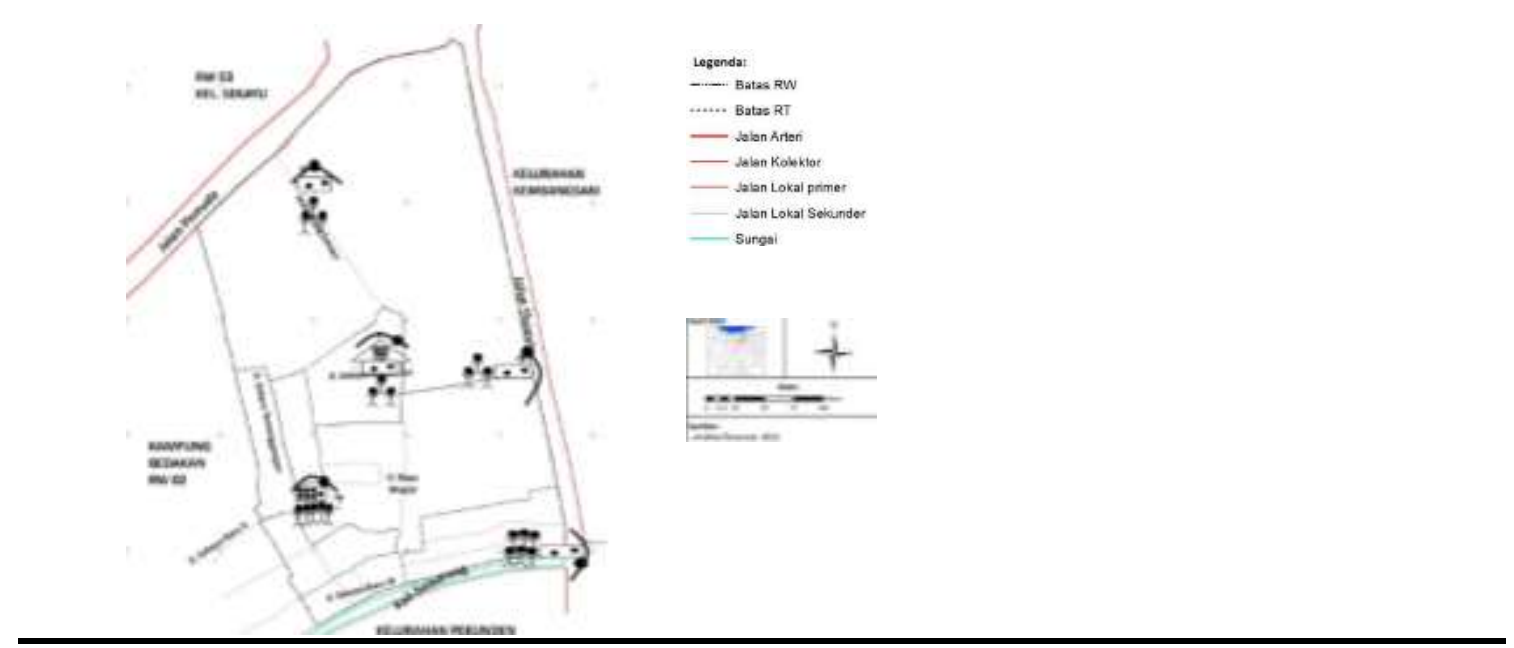

Gambar 8. Model Adaptasi Aktivitas Sebelum Berkembangnya Sektor Perdagangan Formal

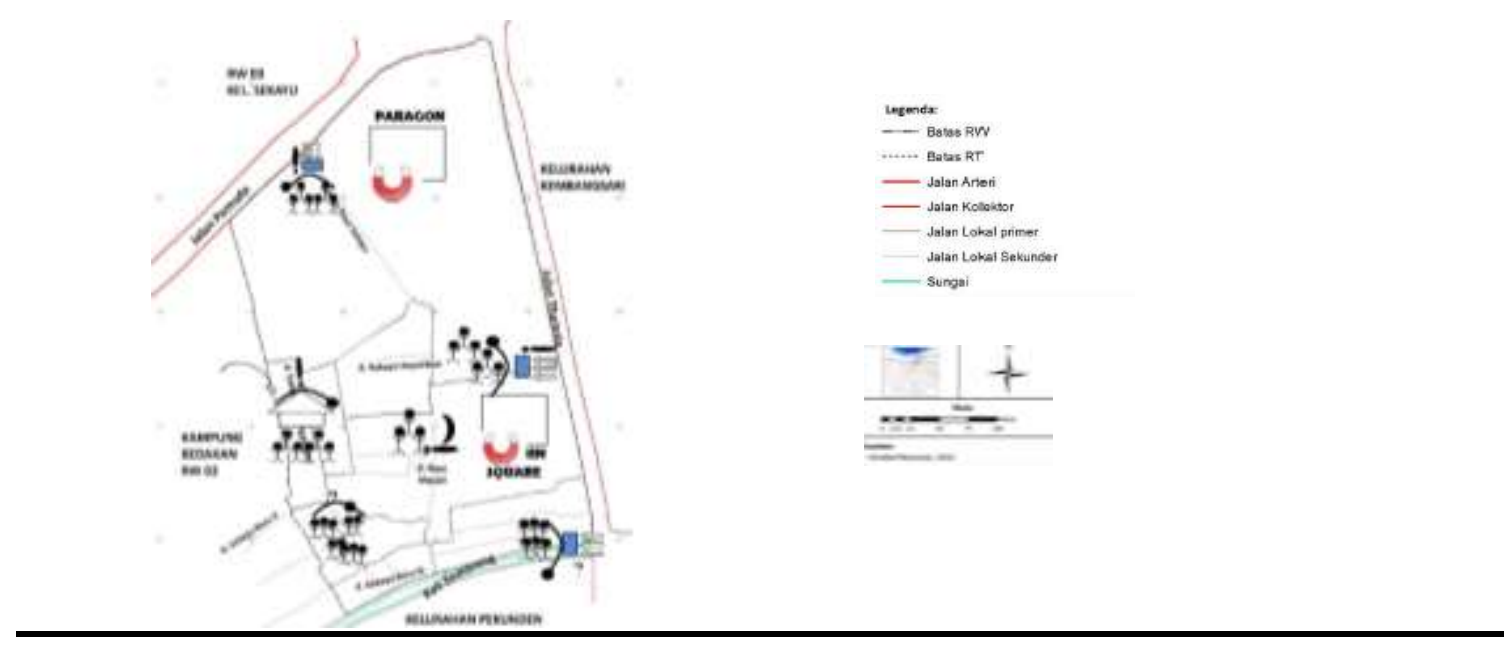

Gambar 9. Model Adaptasi Aktivitas Sesudah Berkembangnya Sektor Perdagangan Formal

\section{A. Model Adaptasi Fisiologi Ruang Kampung Sekayu Terhadap Sektor Perdagangan Formal}

Fisiologi ruang Kampung Sekayu berkaitan dengan fungsi ruang yang terbentuk akibat perkembangan sektor perdagangan formal di lingkungan kampung tersebut. Perubahan fungsi ruang yang ada dipengaruhi oleh aktivitas yang terjadi dan telah diidentifikasi pada bahasan sebelumnya. Bentuk adaptasi dalam hal fisiologi ruang terdiri atas spesifikasi ruang dan dimensi pembentuk ruang.

1) Dimensi Pembentuk Ruang

Dimensi membentuk spesifikasi ruang. Keseluruhan perilaku warga Kampung Sekayu akan membentuk lingkungan spasial yang akan membentuk ruang kampung. 


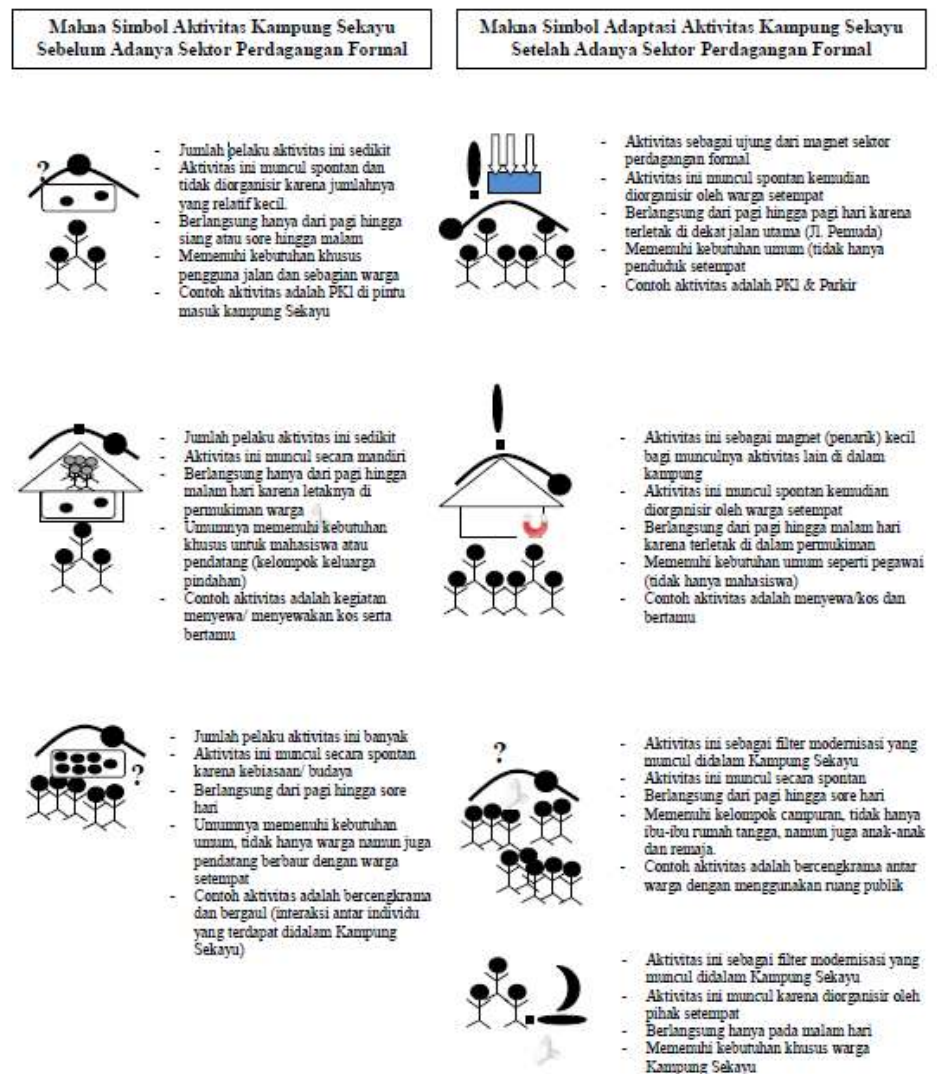

Gambar 10. Makna Simbol Model Adaptasi Aktivitas Warga Kampung Sekayu

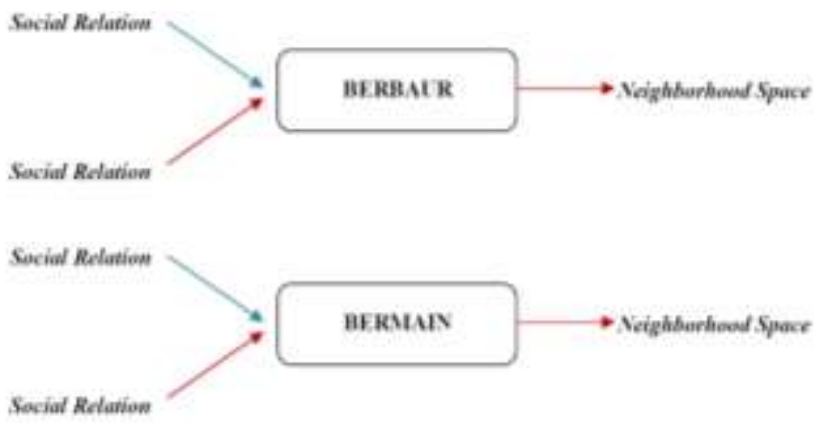

Sumber: Hasil Analisis, 2013

\section{Gambar 11. Diagram Model Adaptasi Dimensi Pembentuk Ruang Kampung Sekayu Akibat Keberadaan Sektor Perdagangan Formal}


2) Spesifikasi Ruang Kampung

Menurut Chombart de Lauwe's (1960) dalam Golledge (1997), ruang prilaku manusia di area perkotaan terlihat dari ruang sosialnya. Terdapat 4 ruang spesifik masyarakat :

- Personal and Family space, atau memperlihatkan karakteritik hubungan antara level rumah tangga dari sebuah interaksi sosial

- Neighborhood space, hubungan kekerabatan yang ditunjukkan dalam kehidupan seharihari dan pergerakan lokal

- Economic space, terkait dengan pusat kegiatan ekonomi tertentu

- Activity space sekaligus sebagai action place (Horton \& Reynold, 1969, 1970)

- Urban sector, atau ruang sosial kota

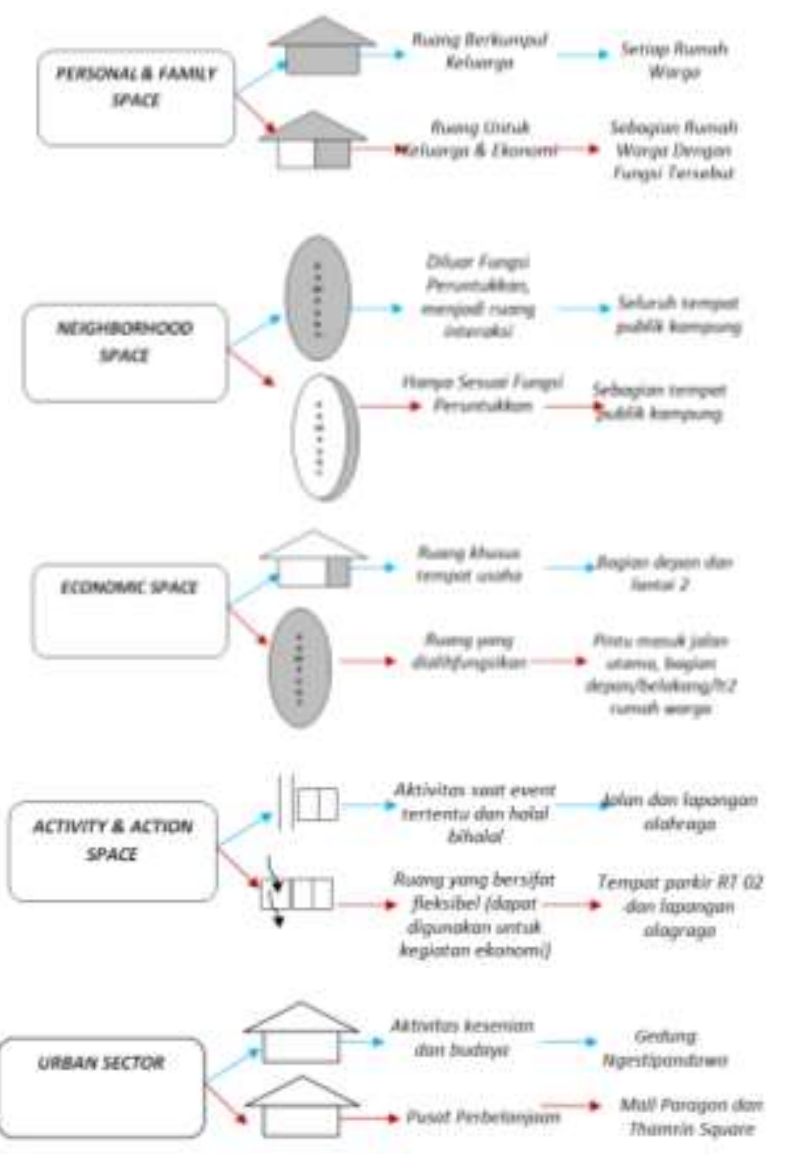

Gambar 12. Diagram Model Adaptasi Fisiologi Ruang Kampug Sekayu

\section{B. Model Adaptasi Morfologi Ruang Kampung Sekayu}

Berdasarkan hasil analisis sebelumnya, teridentifikasi kategori aktivitas dan perilaku warga yang mengalami perubahan sejak perkembangan sektor formal di lingkungan Kampung Sekayu. Aktivitas tersebut tercermin dari fungsi-fungsi ruang publik dan privat yang tercipta di dalam kampung. Dari dasar inilah maka dapat dilihat bentuk morfologi ruang Kampung Sekayu sesuai dengan perilaku warga. 


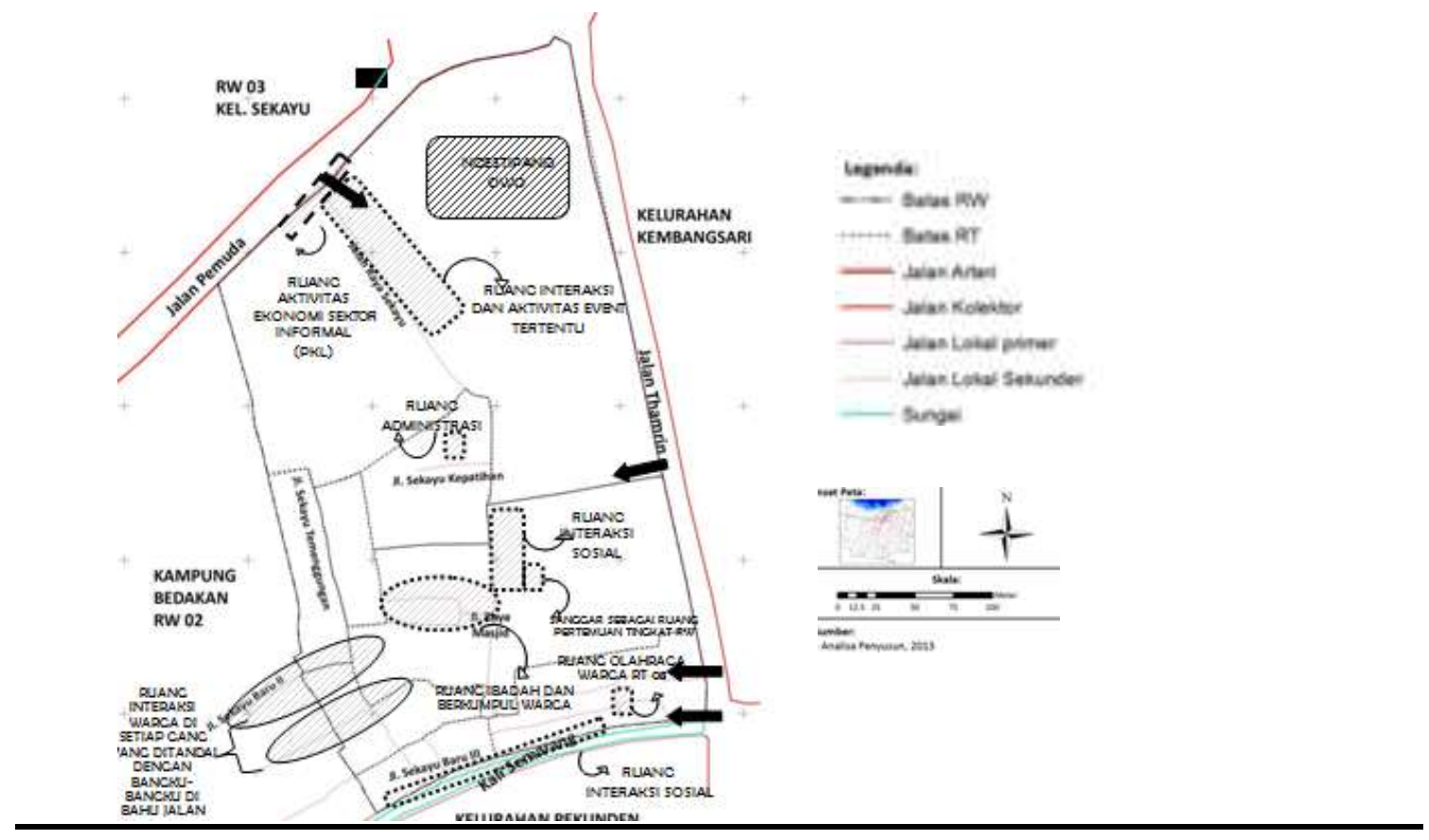

Gambar 13. Model Sistem Permukiman Kampung Sekayu Sebelum Berkembangnya Sektor Perdagangan Formal

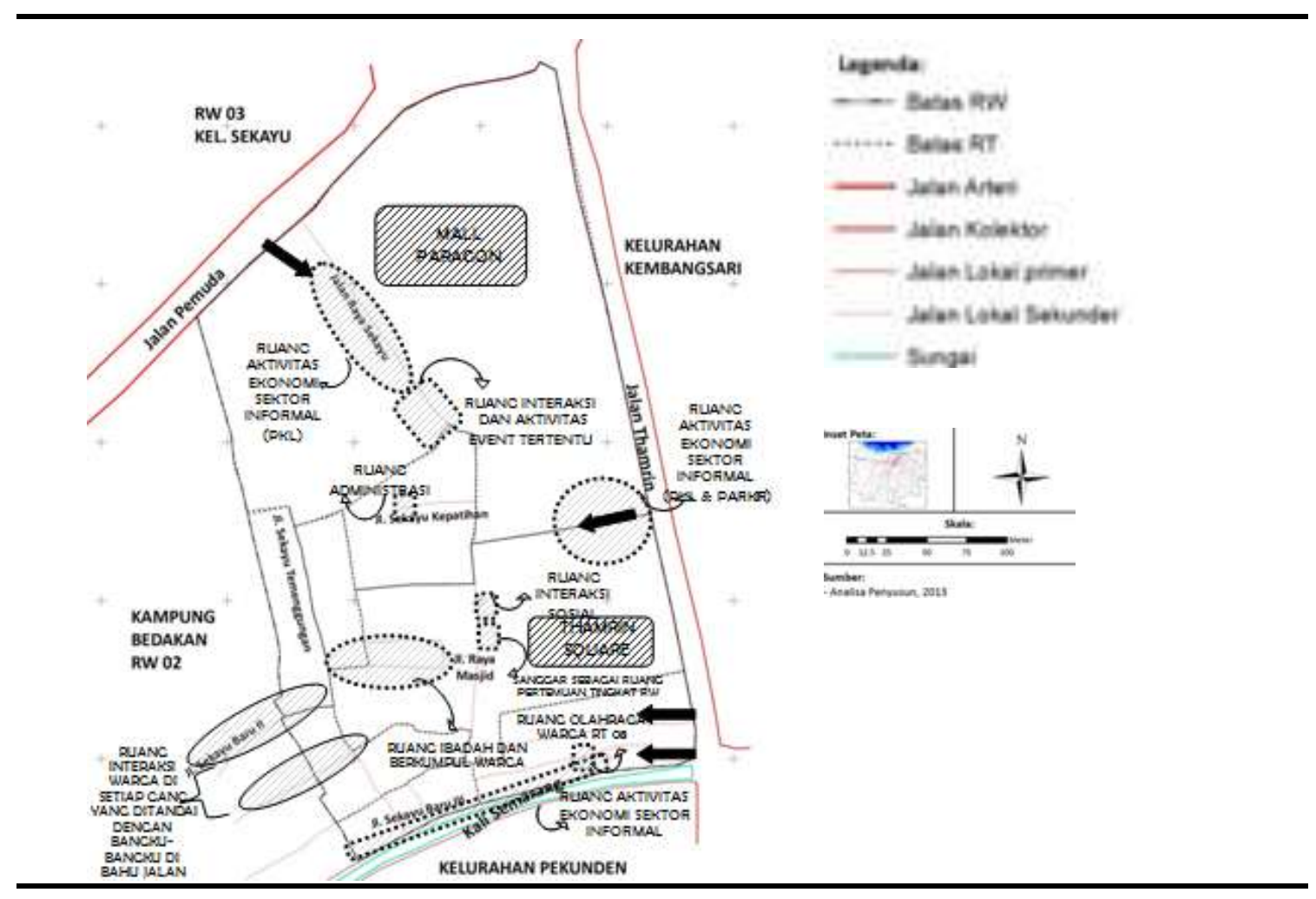

Gambar 2. Model Sistem Permukiman Kampung Sekayu Setelah Berkembangnya Sektor Perdagangan Formal 


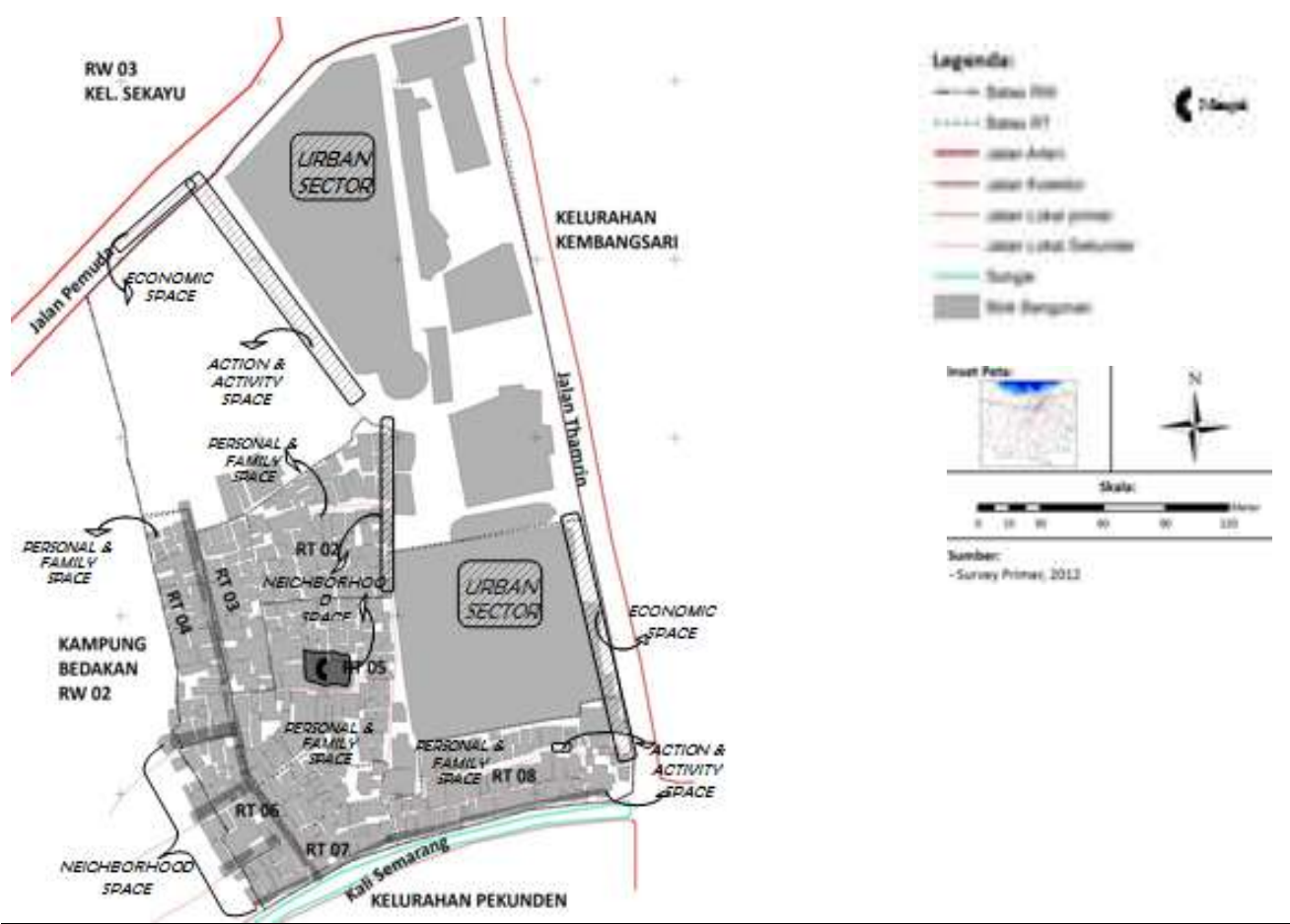

Gambar 35. Model Spesifikasi Ruang Kampung Sekayu Sebelum Berkembangnya Sektor Perdagangan Formal

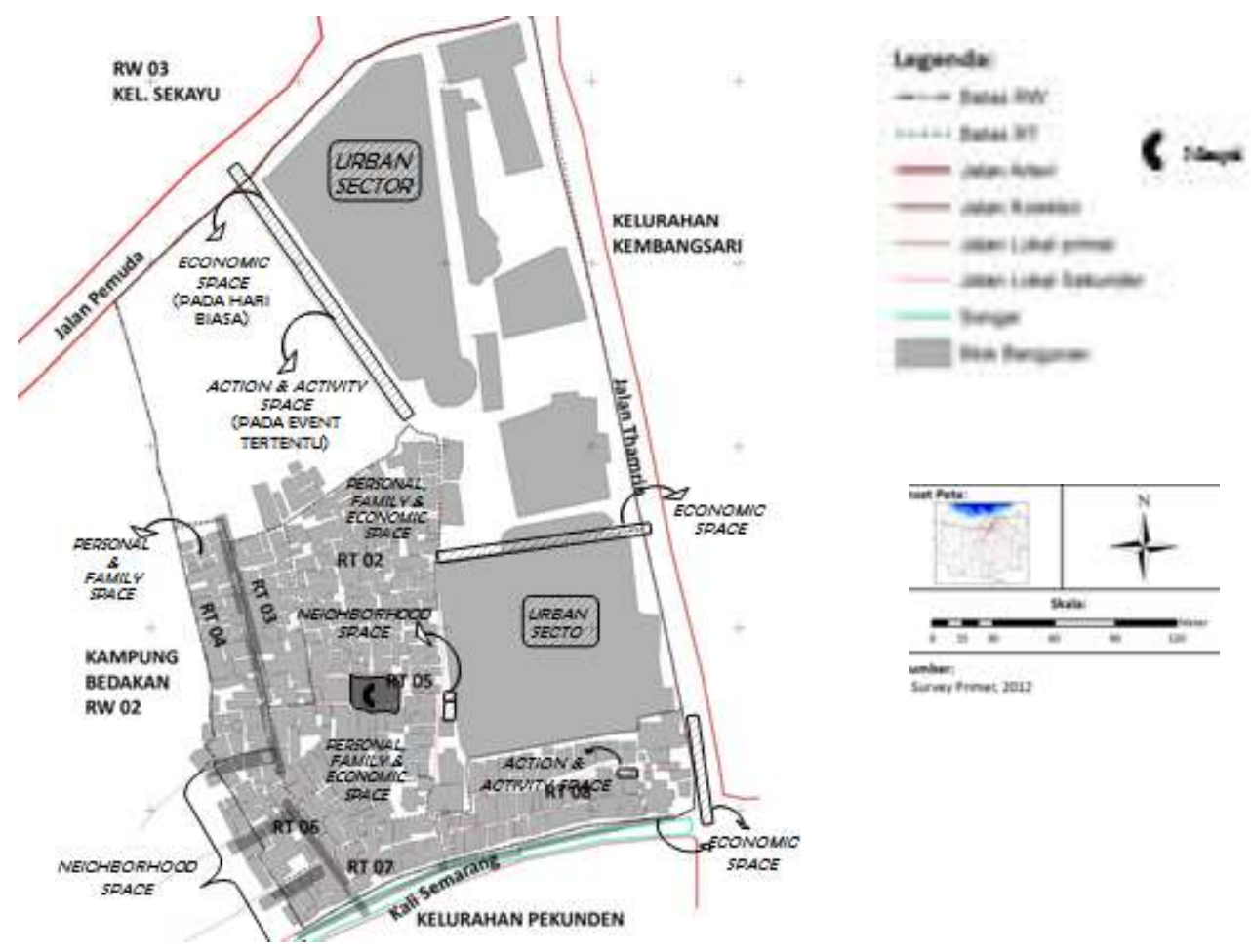

Gambar 16. Model Spesifikasi Ruang Kampung Sekayu Setelah Berkembangnya Sektor Perdagangan Formal 
1) Struktur Fungsi

Struktur ini membagi fungsi-fungsi secara kuantitatif dan kualitatif dalam fungsi publik dan privat sesuai kebutuhan dalam kawasan yang berlangsung secara mono atau multifungsi. Fungsi ini berkaitan dengan aktivitas yang dilakukan warga Kampung Sekayu. Kecenderungan perubahan struktur fungsi terlihat dari ekspresi, perhatian dan mono-multi ruang yang terbentuk.

\section{2) Struktur Sirkulasi}

Sebelum adanya berkembangnya sektor perdagangan formal, kondisi jalan di Kampung Sekayu tidak seramai saat ini. Frekuensi dan kuantitas kendaraan yang lewat sebagian besar diakses oleh warga Kampung Sekayu sendiri dan beberapa warga dari kampung sekitar. Namun sejak berkembangakn sektor tersebut, jalan-jalan di Kampung Sekayu diakses juga oleh pengguna eksternal yang bertujuan ke sektor tersebut (untuk Jalan Sekayu Raya). Peningkatan frekuensi dan kuantitas juga terjadi di jalan lingkungan karena semakin bertambahnya jumlah penyewa kos dan jumlah kunjungan/ bertamu yang juga meningkat. Peningkatan volume didalam Kampung Sekayu sendiri menyebabkan :

- Ruang publik semakin berkurang karena digunakan sebagai tempat parkir oleh penduduk

- Salah satu jalan diberi tiang penghalang untuk kendaraan roda 4 (di RT 02)

- Beberapa jalan (gang) diberi portal keamanan untuk membatasi aktivitas keluar-masuk Kampung Sekayu hingga pukul tertentu.

- Untuk membatasi laju kendaraan, beberapa ruas jalan diberi tali tambang yang dibuat melintang lebar jalan.

- Tingkat keamanan dan kenyamanan warga penduduk asli Kampung Sekayu semakin berkurang.

- Interaksi sosial terganggu karena banyaknya kendaraan yang melintas
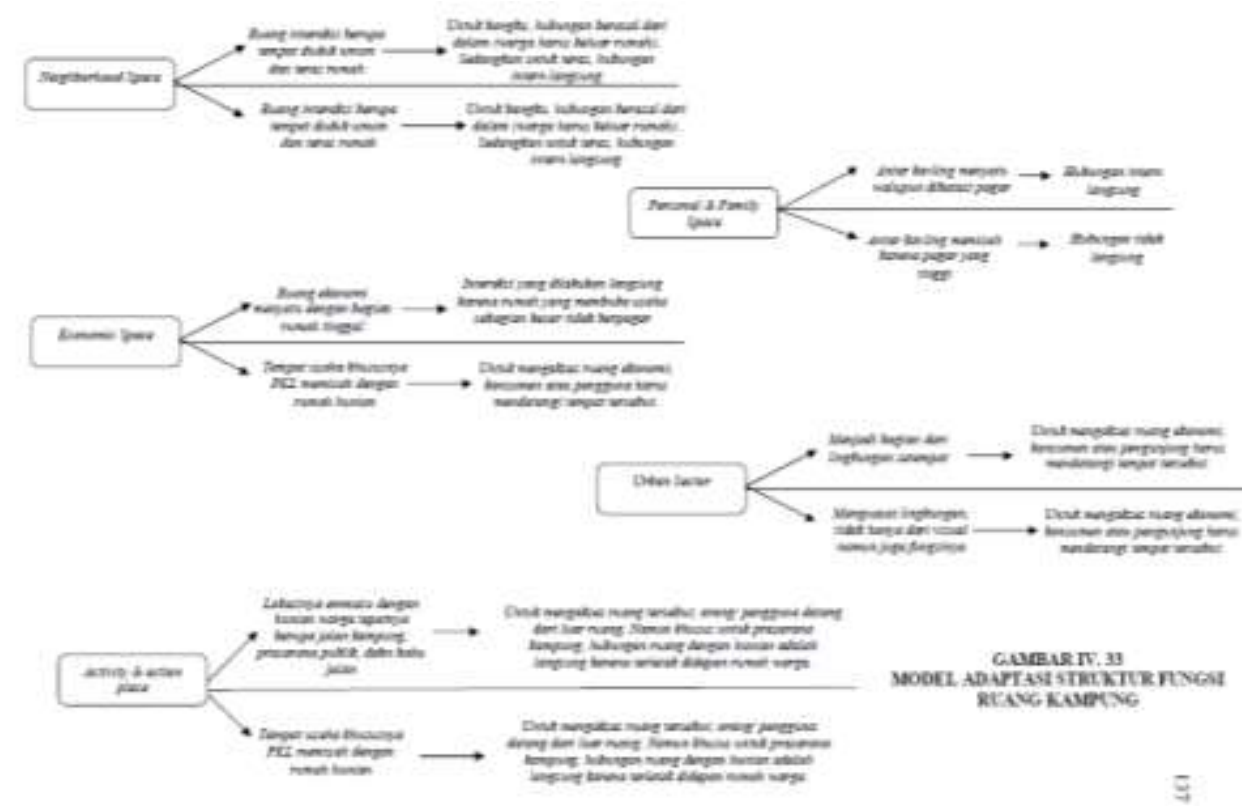

Gambar 17. Model Adaptasi Struktur Fungsi Ruang Kampung 


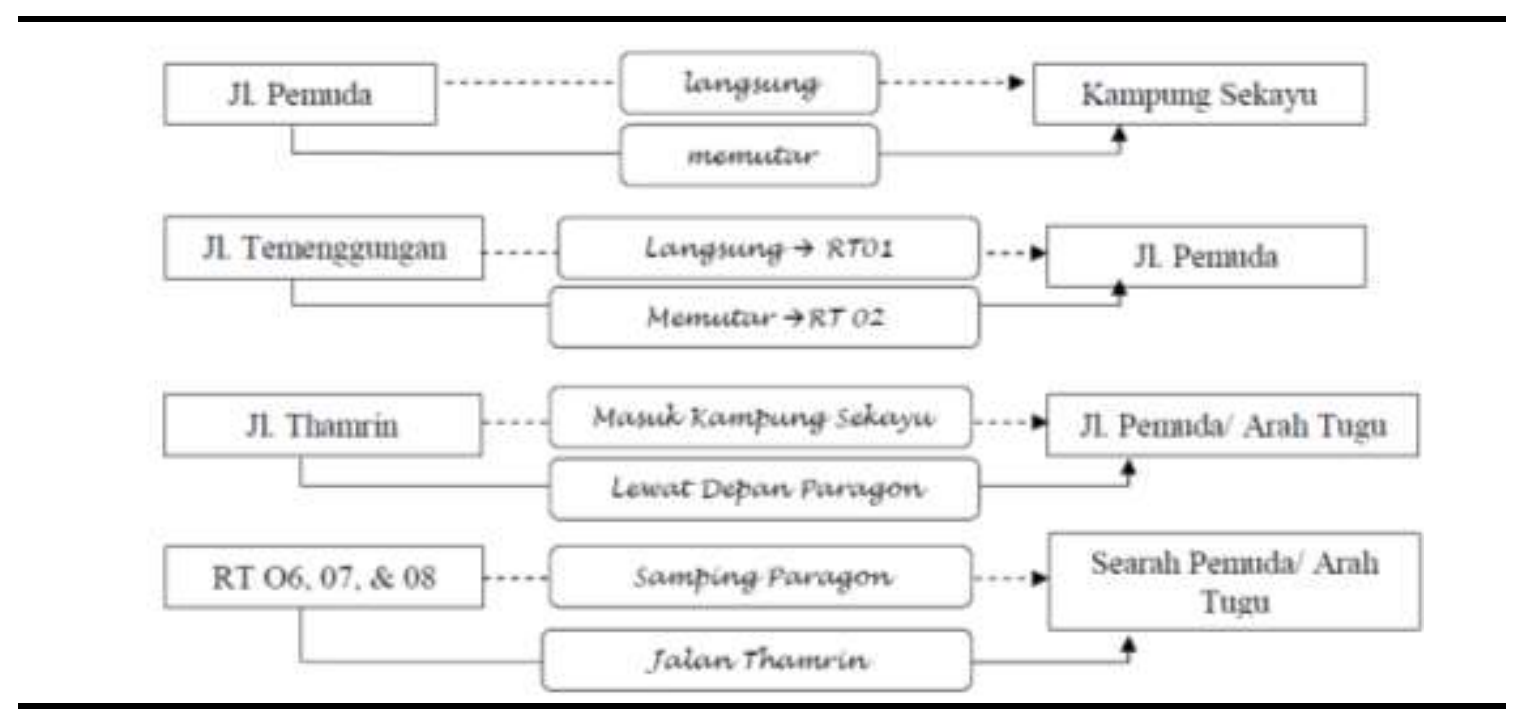

Gambar 18. Diagram Model Adaptasi Arah Pergerakan Warga Kampung Sekayu

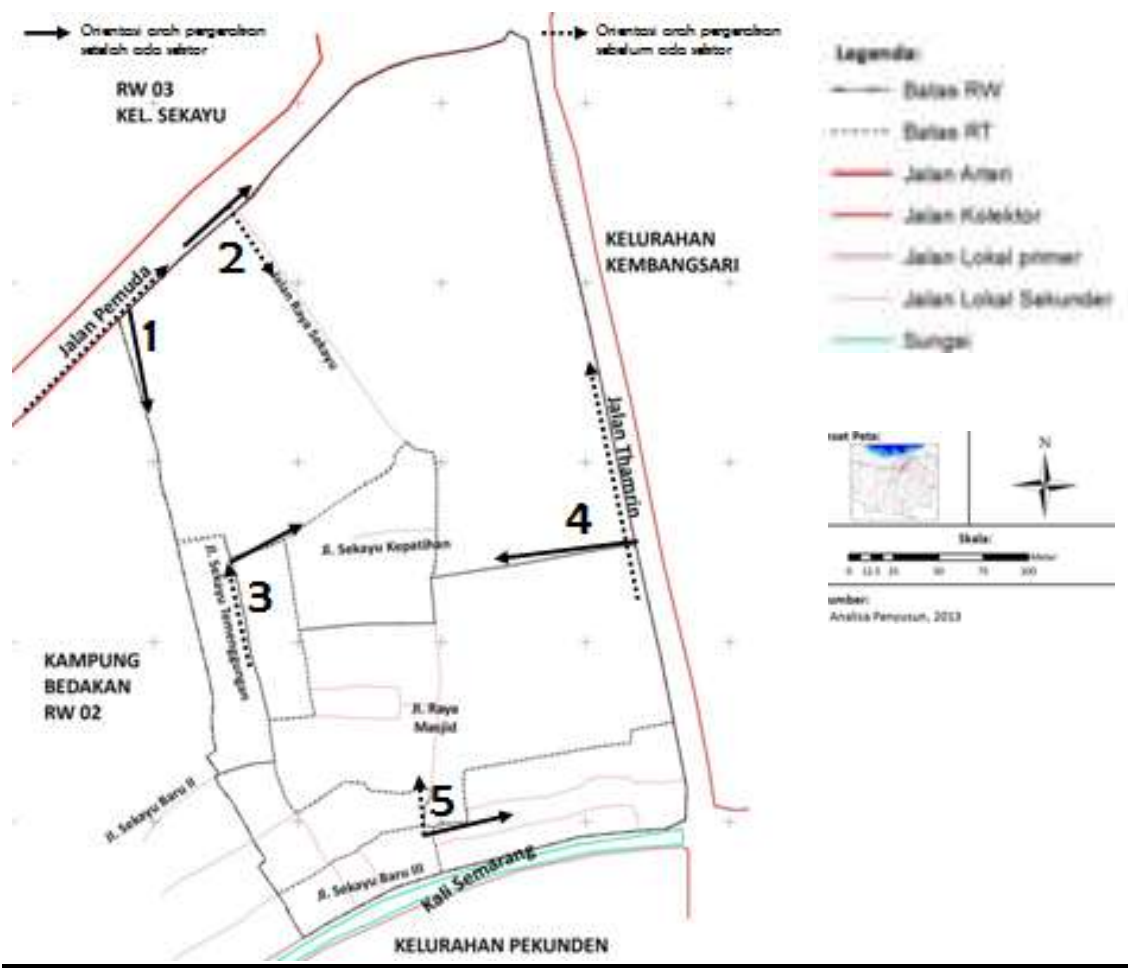

Gambar 19. Digram Model Adaptasi Orientasi Pergerakan Warga Kampung Sekayu

3) Struktur Kavling

Kavling bangunan sejak perkembangan sektor perdagangan formal mengalami perubahan dibeberapa hal. Menurut Zhand (2008), kriteria penilaian perubahan dilihat dari struktur kavling adalah :

- Hubungan kavling dengan kekuatan ekonomi

- Jumlah dan ukuran kavling 
- Bentuk kavling

- Fokus kavling, dan

- Posisi kavling

- Sebelum berkembangan sektor

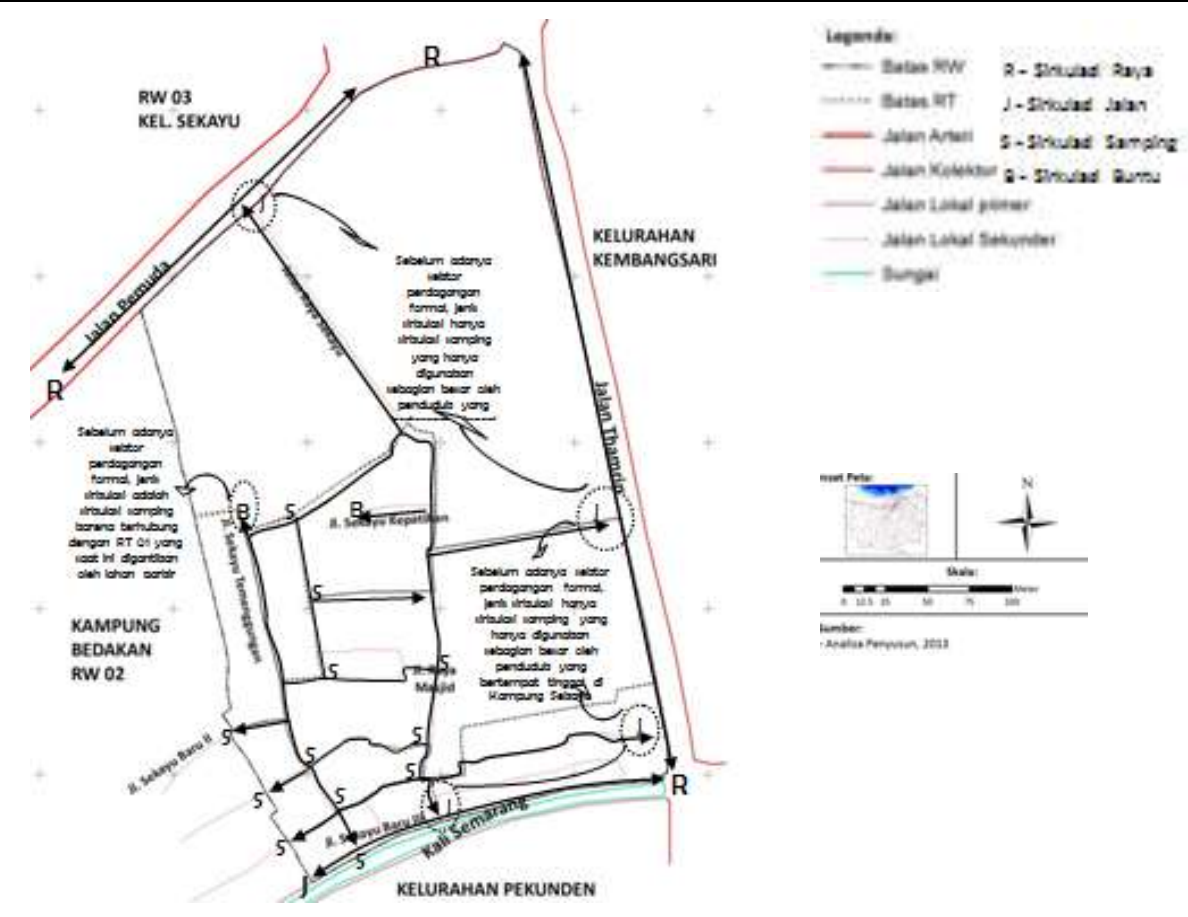

Gambar 20. Jenis Sirkulasi Kampung Sekayu Sejak Berkembangnya Sektor Perdagangan Formal
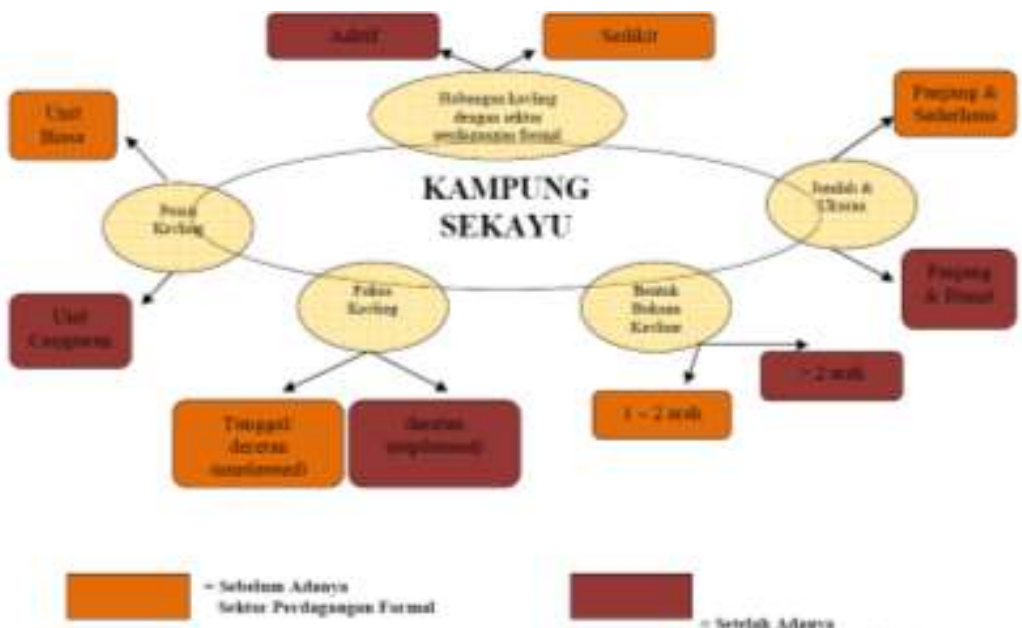

Gambar 21. Diagram Model Adaptasi Struktur Kavling Kampung Sekayu Akibat Keberadaan Sektor Perdagangan Formal 
4) Organisasi Ruang

Organisasi ruang sendiri menurut rapoport (1977), terdiri dari 3 unsur yaitu ruang bermukim, ruang interaksi (bertemu), dan jalan sebagai pemisah. Dengan melihat kondisi eksisting yang terdapat di Kampung Sekayu, organisasi ruang yang terbentuk baik sebelum maupun setelah perkembangan sektor perdagangan formal, tidak banyak mengalami perubahan. Hanya frekuensi dan kuantitas yang dirasa berbeda.

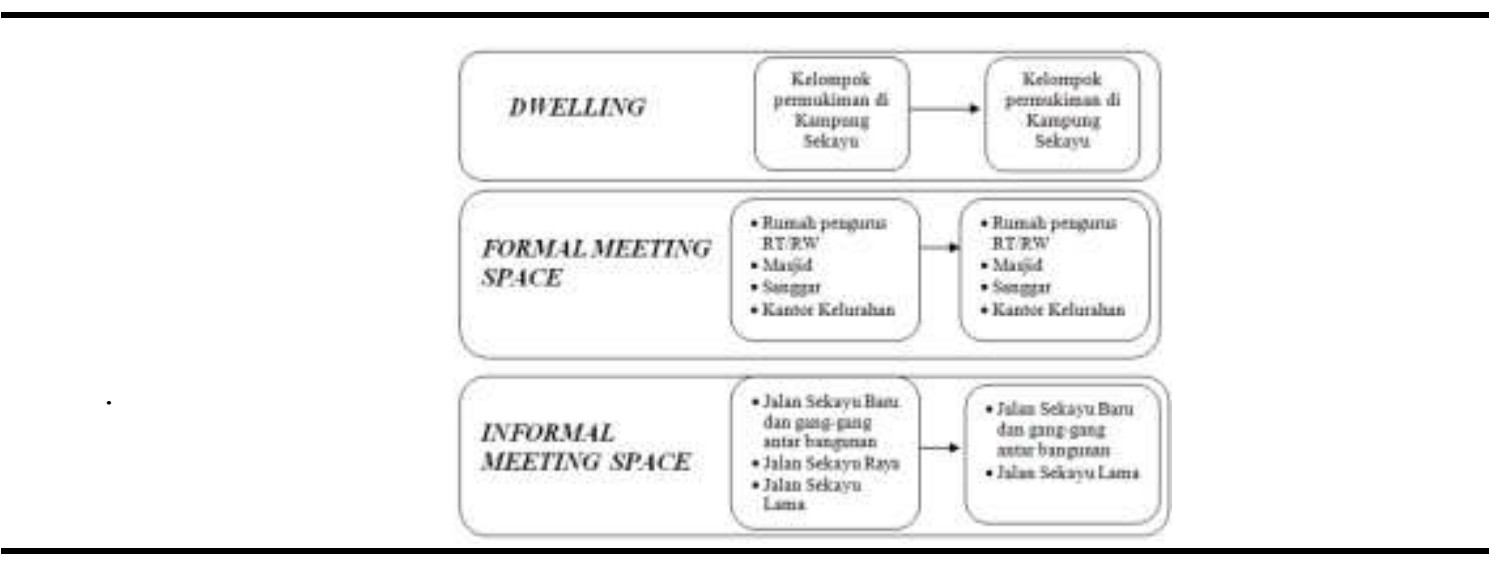

Gambar 22. Diagram Model Adaptasi Organisasi Ruang Kampung Sekayu Sejak Keberadaan Sektor Perdagangan Formal

\section{Hubungan Teori Dengan Temuan Penelitian}

Secara keseluruhan, berdasarkan hasil kajian yang telah dilakukan sebelumnya, model perubahan atau adaptasi ruang yang dibentuk oleh warga Kampung Sekayu sebelum berkembangnya sektor perdagangan formal adalah sebagai berikut :

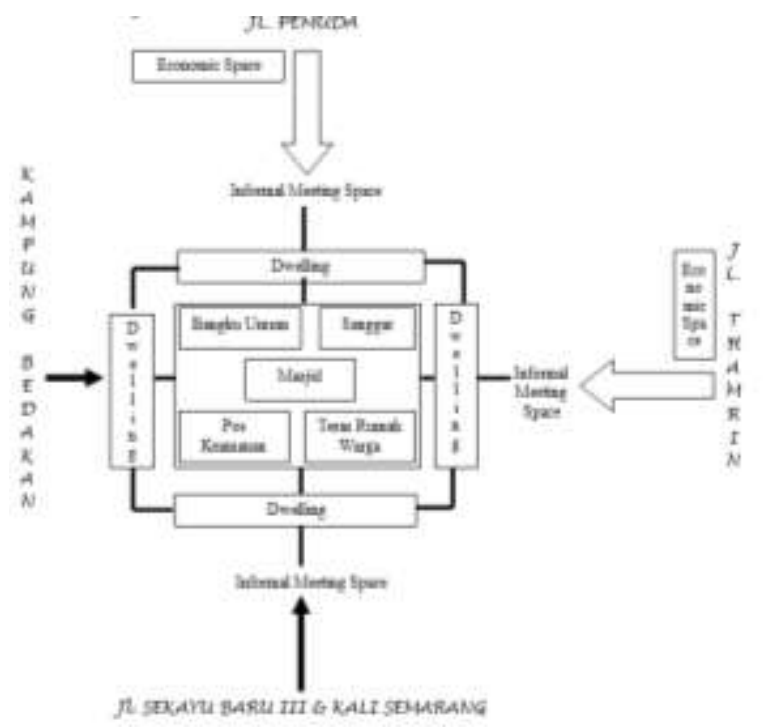

Gambar 23. Model Adaptasi Ruang Kampung Sekayu Sebelum Berkembangnya Sektor Perdagangan Formal 
Sedangkan setelah berkembangnya sektor perdagangan formal di lingkungan Kampung Sekayu, model adaptasi ruang yang terbentuk adalah sebagai berikut :

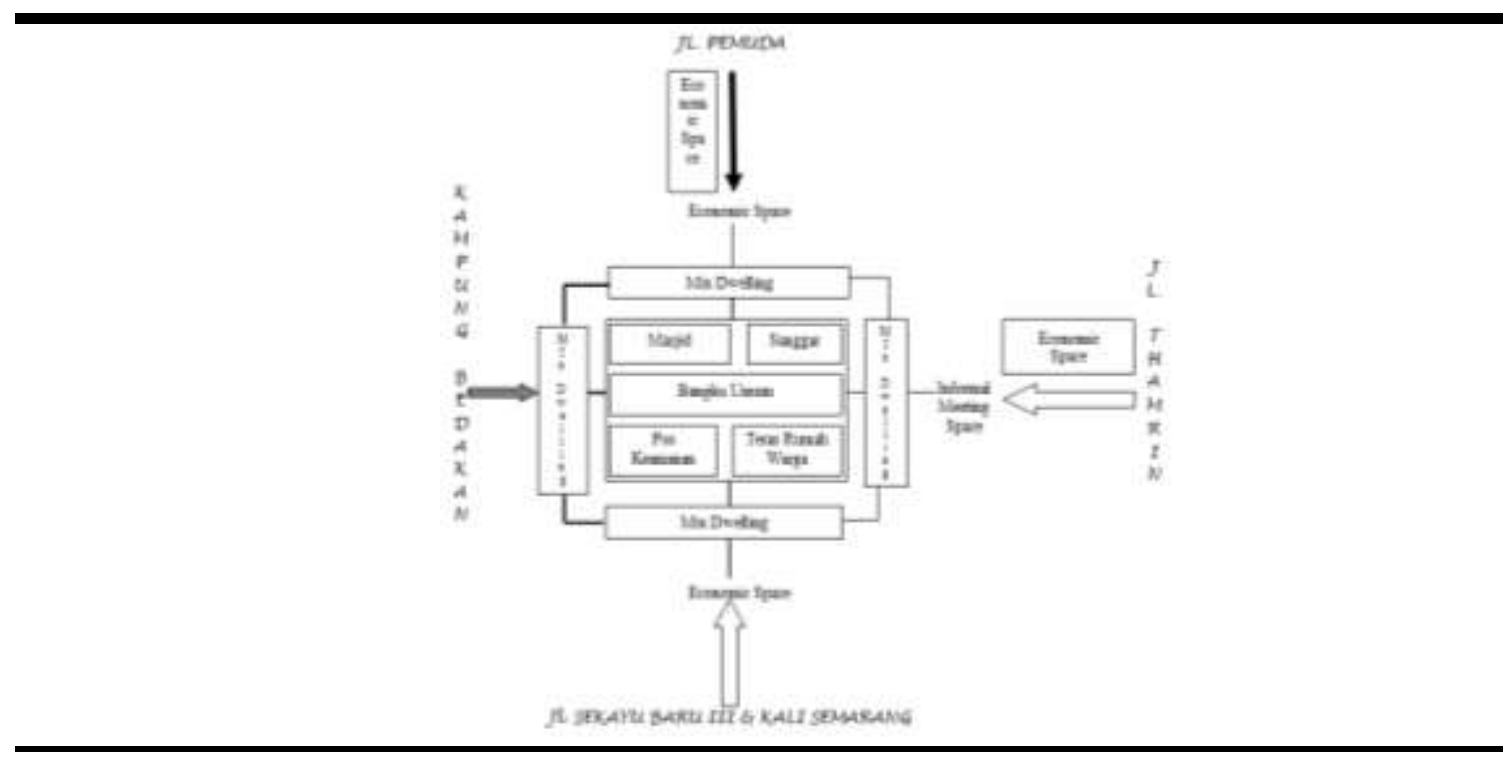

Gambar 4. Model Adaptasi Ruang Kampung Sekayu Setelah Keberadaan Sektor Perdagangan Formal

Dalam teorinya Lazarus (1984) mengatakan bahwa bentuk penyesuaian terhadap lingkungan terdiri atas dua yaitu Adaptasi dan Adjustment. Penggambaran model penyesuaian yang telah dipaparkan sebelumnya memperlihatkan bahwa untuk model aktivitas dapat dikatakan sebagai sebuah adaptasi. Hal ini disebabkan karena aktivitas yang dilakukan warga Kampung Sekayu menunjukkan respon yang disesuaikan dengan lingkungan. Warga berusaha menjadi bagian dari berkembangnya sektor perdagangan formal yang cukup pesat. Wujud nyata adalah dengan munculnya beberapa aktivitas pendukung sektor perdagangan formal seperti PKL, parkir, kos, usaha rumahan lainnya yang secara langsung terhubung dengan keberadaan sektor tersebut.

Setiap aktivitas membutuhkan ruang sebagai wadah. Berdasarkan hasil pemodelan ruang yang terbentuk di Kampung Sekayu maka dapat dikatakan bahwa penyesuaian yang terjadi merupakan bentuk adjustment. Warga Kampung Sekayu memfungsikan ruang yang ada diluar dari fungsi awal ruang tersebut digunakan. Misalnya pada model fungsi ruang, terlihat bahwa sebelum berkembangnya sektor perdagangan formal, ruang hunian bersifat sebagai personal private. Namun saat ini, ruang didalam hunian terbagi menjadi personal private space dan economic space. Kondisi ini terjadi karena melihat peluang keberadaan sektor perdagangan formal di lingkungan Kampung Sekayu sehingga kecenderungan mengalihfungsikan ruang yang dimiliki pun semakin besar

\section{Kesimpulan}

Berdasarkan hasil kajian yang tercantum pada bab sebelumnya, maka dapat disimpulkan beberapa hal mengenai model adaptasi ruang kampung kota di Kampung Sekayu sebagai berikut :

Penyesuaian aktivitas yang dilakukan warga Kampung Sekayu termasuk dalam kategori adaptasi. Perubahan dilihat dari fokus aktivitas, jenis aktivitas, waktu aktivitas, dan 
keterkaitan aktivitas. Berdasarkan hasil analisis diketahui bahwa adaptasi terjadi pada kegiatan sewa-menyewa, PKL, parkir, dan usaha lainnya dimana sebelumnya jumlah warga yang terlibat dalam aktivitas ini sangat kecil dan keberadaannya tidak diorganisir. Namun karena melihat peluang ekonomi yang cukup besar sejak mulai bermunculannya sektor perdagangan formal dan meningkatkan permintaan akan sektor informal sebagai pendukung maka saat ini aktivitas tersebut semakin menjamur di Kampung Sekayu. Bahkan beberapa penduduk Kampung Sekayu memilih untuk beralih profesi menjadi tukang parkir atau membuka usaha dagangan karena alasan peningkatan taraf ekonomi keluarga. Sedangkan untuk aktivitas sosial seperti bercengkrama dan bertegur sapa antara pendatang (anak kos) dan warga setempat juga mengalami penyesuaian. Saat ini kecenderungan aktivitas tersebut dilakukan semakin kecil dengan intensitas waktu dan kuantitas orang yang terlibat mengalami penurunan.

Perubahan aktivitas warga Kampung Sekayu menyebabkan beberapa fungsi ruang juga mengalami perubahan atau dapat dikatakan menyesuaikan dengan lingkungan yang dikelilingi oleh sektor perdagangan formal. Model penyesuaian fisiologi ruang menggambarkan bentuk penyesuaian secara adjustment. Dicontohkan keberadaan sektor perdagangan formal menyebabkan munculnya beragam usaha yang menjadi pendukung sektor tersebut, salah satunya usaha kos. Sebelumnya pemilik hunian memfungsikan keseluruhan ruang di dalam rumahnya sebagai ruang privat dan keluarga. Namun dengan melihat peluang ekonomi yang ditimbulkan kondisi sekitar, maka sebagian ruang rumah dijadikan sebagai ruang bagi kegiatan usaha seperti warung atau disewakan untuk menjadi tempat kos. Pemilik pun membagi fungsi rumah. Umumnya lantai 1 atau bagian depan rumah dijadikan sebagai ruang pribadi pemilik rumah. Sedangkan lantai 2 atau bagian belakang rumah disewakan untuk kepentingan ekonomi.

Bentuk penyesuaian yang terakhir adalah morfologi ruang kampung yang digunakan oleh warga dimana bergantung pada fungsi ruang yang diberlakukan sesuai dengan aktivitas yang terjadi. Penyesuaian morfologi ruang ini pun merupakan bentuk penyesuaian secara adjustment. Adaptasi morfologi ruang dilihat dari struktur fungsi, struktur sirkulasi, struktur kavling, dan organisasi ruang. Dari hasil pemodelan penyesuaian morfologi ruang maka kecenderungan untuk aktivitas sosial saat ini berlangsung di sebelah barat Kampung Sekayu (RT 03,04,06,dan 07) atau pada wilayah RT yang tidak dilalui Jalan Raya Sekayu. Hal ini disebabkan karena volume kendaraan atau pergerakan di Jalan Raya Sekayu yang mengalami peningkatan. Sedangkan diketahui bahwa jalan tidak hanya menjadi ruang sirkulasi namun juga menjadi media warga untuk berinteraksi. Dari model penyesuaian morfologi/ bentuk pun memperlihatkan warga mencoba membentuk permukiman mereka agar tetap kondusif dengan memberikan palang di beberapa ruas jalan dan diaktifkan hingga batas waktu berkunjung

\section{Daftar Pustaka}

Arikunto, Prof.Dr.Suharsimi. 1998. Prosedur Penelitian : Suatu Pendekatan Praktek. Jakarta : PT. Rineka Cipta. Anthony J, Catanese, C-Sayder. 1988. Perencanaan Kota. Jakarta : PT Gelora Aksara Pratama.

Bintarto. 1983 Urbanisasi dam Permasalahannya, Yogyakarta : Galia Indonesia.

Bungin, Dr.H.M Burhan. 2007. Penelitian Kualitatif. Jakarta : Kencana Prenada Media Group.

Cozby, Paul C. 2005. Methods In Behavioral Research. New York : McGrow Hill Companies Inc.

Dey, Ian. 1993. Qualitative Data Analysis : A User-Friendly Guide For Social Scientists. London \& New York : Routledge Taylor \& Francis Group.

Gifford. 1987. Environmental Pshycology:Principles And Practice. Boston : Allyn \& Bacon, Inc.

Ghozali. 2005. Aplikasi Analisis Multivariate Dengan Program SPSS. Semarang : Badan Penerbit UNDIP.

Holahan, C.J. 1982. Environmental Pshycology. New York : Random House 
Hunt, Chester L. 1984. Sosiologi. Erlangga : Jakarta

King, Leslie J \& Reginald G Golledge. 1978. Cities, Space, And Behavior : The Elements Of Urban Geography. New Jersey : Prentice-Hall Inc.

Kerlinger, Fred N. 1993. Asas-Asas Penelitian Behavioral. Yogyakarta : Gadjah Mada University.

Laurens, Marcella Joyce. 2004. Arsitektur dan Perilaku Manusia. Jakarta : PT. Grasindo.

Lazarus, Richard S \& Susan Folkman. 1984. Stress, Appraisal, and Coping. New York : Springer Publishing Company.

Muhadjir, Prof.Dr.H.Noeng. 1996. Metode Penelitian Kualitatif. Yogyakarta : Rake Serasin.

Rapoport, Amos. 1969. House Form And Culture. Prentice Hall Inc, Englewood, Cliffs, NJ

Rapoport, Amos. 1977. Human Aspect Of Urban Form. Oxford : Pergamon Press.

Sarwono, Sarlito WIrawan. 1992. Psikologi Lingkungan. Jakarta : Grasindo.

Schneiders, A. 1964. Personal Adjustment and Mental Health. New York: Rinehart \& Winston.

Singarimbun, Masri \& Sofian Effendi. 1989. Meteode Penelitian Survei. Jakarta : LP3ES.

Soemarwoto. 1991. Ekologi, Lingkungan Hidup, dan Pembangunan. Jakarta : Penerbit Djambatan

Soetomo, Sugiono. 2009. Urbanisasi dan Morfologi Proses Perkembangan Peradaban \& Wadah Ruang Fisiknya : Menuju Ruang Kehidupan yang Manusiawi. Yogyakarta : Graha Ilmu

Sugiyono, Wibowo. 2001. Statistika Penelitian dan Aplikasinya dengan SPSS ver 10.o for windows. Bandung : Alfabeta.

Zahnd, Markus. 2008. Model Baru Perancangan Kota yang Kontekstual : Kajian Tentang Kawasan Tradisional di Kota Semarang dan Yogyakarta. Suatu Potensi Perancangan Kota yang Efektif. Yogyakarta : Kanisius.

Rudito, Bambang dan Famola, Femia. 2008. Social Mapping (Metode Pemetaan Sosial) Teknik Memahami Suatu Masyarakat. Bandung : Rekayasa Sains.

Worang, Buddy L. 1973. Pengantar Sosiologi. Yogyakarta : Universitas Atma Jaya 